\author{
By \\ Gehad Hassan Ali Elkomy \\ A teacher of English at Pakistan Excel English School \\ (Kuwait)
}

\author{
Supervisors \\ Prof: Aly Abdul Samea Qoura \\ Dr: Samah Rezk Hassan
}

Journal Of The Faculty Of Education- Mansoura University

No. 111 - July. 2020 


\title{
A Massive Open Online Course (MOOC) to Develop EFL Secondary School Students' Listening and Speaking Skills and their Self- Directed Learning
}

\begin{abstract}
This study aimed at investigating the effectiveness of using Massive Open Online Courses (MOOCs) on developing EFL secondary school students' listening and speaking skills and their self-directed learning. The study adopted the quasiexperimental design with one experimental group pre-posttest. The sample of the study consisted of 20 students of the $1^{\text {st }}$ secondary stage at Future Language Schools in Tanta who represented the experimental group and was taught through the MOOC. Data was collected through using the following instruments: course topics checklist to determine the most interesting topics that students would like to practice during the course, pre-post EFL listening comprehension skills test, prepost EFL speaking skills test with speaking assessment rubric and a self-directed learning scale $(S D L S)$. Findings of the study revealed that there was a statistically significant difference between the mean scores of the experimental group students on the pre and post administrations of the listening and speaking tests in addition to the self-directed learning scale in favor of the post administration. The effect size of the course was found to be high and it was recommended to use MOOCs as an effective technique in teaching EFL skills.
\end{abstract}

\section{Introduction:}

Learning English represents a necessity for students in different countries around the world especially where the medium of instruction is English. The growing demand for communication on international level has earned English language the status of language of communication, the thing that increased the demand for developing English language among nonnative speakers all over the world. In order to develop good communication skills, a strong interest in listening and speaking skills must be taken into consideration.

Indeed, mastering listening and speaking skills is crucial for language learning. The ability to speak opens up wider opportunities to achieve success in life. People are judged from the way they speak (Samurada, 2016). It is known that speaking cannot be separated from listening since they are interrelated. Richards (2008) states that the main function of listening in second language learning is to facilitate understanding of spoken discourse. In schools, however, listening and speaking receive little attention in the learning process. Listening and speaking skills tend to be the 
most difficult skills for teachers to teach because of some reasons related to the planning and learners' attitude (Wilson, 2008).

Many strategies have been used to develop listening and speaking skills within the classroom either through face-to-face interaction or through new technological methods or combining both of them which is known as blended-learning. New educational scenarios have been recently adapted by universities, which create a set of challenges and opportunities, most of them are related to the use of technology in education. Technological and multi-tool learning environments are gaining momentum. There has been a shift from centralized, specialized, owned systems (VLE, LMS) towards distributed, general-purpose, user-centered, and user-owned systems, such as social software tools.

Massive Open Online Courses (MOOCs) are one of the advanced technologies in the field of education. The term Massive Open Online Courses (MOOCs) was first introduced in 2008 by Dave Cormier to describe Siemens and Downes' (as cited in Herman, 2012) "Connectivism and Connective Knowledge" course. Oxford Online Dictionaries (n. d.) define a MOOC as a course of study made available over the internet without charge to a very large number of people. MOOCs typically differ from "regular" online courses in that: (a) those participating are not registered students at the school. (b) they are designed for unlimited participation and open access via the web - no tuition is charged. (c) there is typically no credit given for completion of the MOOC (Allen \& Seaman, 2014).

The philosophy of MOOCs is derived from connectivism which emphasizes the deschooling philosophy of education. According to Kop and Hill, connectivism gives importance to two skills that contribute to learning, which are nothing but, "ability to seek out current information and the ability to filter secondary and extraneous information" (Kop and Hill, 2008, p. 2). Downes (2010) pinpoints that MOOCs are a society where knowledge and learning are public goods, freely created and shared, not hoarded or withheld in order to extract wealth or influence.

One of the basic features of MOOCs is that "it enables participants to connect outside the traditional learning environment, thereby offering autonomy, openness and emergent knowledge" (Viswanathan, 2012, p. 1). That is to say MOOCs enable learners to discover and apply underlying structure to their perspective on a course according to their own experience and notions of learning. Thus, the successful learners utilize the internet to find their learning goals, MOOCs in fact provide learners with suitable 
materials to reach their goals. They enable students to be lifelong learners and develop their self-directed learning.

Self-Directed Learning (SDL) is a concept that attracts the attention of researchers as a subject of investigation in adult education field since the early 20th century (Gibbons, 2002). It is a procedure which gives students

opportunities to be independent of their teachers in deciding the learning goals, selecting the learning task that they can accomplish and in completing it (Jossberger, et al., 2010). It is considered as lifelong learning (Candy,1991; O'Shea, 2003). University students should not only master educational information, but they should also enjoy having SDL skills as well (Areglado, Bradley, \& Lane, 1996). Therefore, significant literature recommended instructional designs and faculty practices conducted to foster SDL among learners in order to enable them to pass their recent and future learning (Shaikh, 2013).

Thus, the present study will investigate the effectiveness of using a proposed Massive Open Online Course (MOOC) to develop EFL secondary school students' listening and speaking skills and their self-directed learning.

\section{Related Studies}

The following are some studies related to listening comprehension:

Yu Tai (2016) conducted a study to investigate the effect of discourse markers (DMs) on EFL learners' listening comprehension. A total of 72 ninth-grade students were assigned as the sample of the study and randomly divided into DM and non-DM groups. The DM group received 14 weeks of DM instruction and a post-test including multiple choice questions, recall questions and a summary was applied on both groups to compare their comprehension scores. The results showed that the DM group outperformed the non- DM group.

Saqr (2016) investigated the effectiveness of flipped classroom approach on improving EFL preparatory school students listening comprehension skills. The researcher adopted the quasi experimental design using two groups: an experimental group that received the experiment using the flipped classroom approach and a control group received the course using the regular way. A pre- post listening skills test was applied on both groups and the results indicated the effectiveness of flipped classroom approach on improving the listening skills of the experimental group.

Woottipong (2014) conducted a study to investigate the effect of using video materials on developing the listening skills of university students and to evaluate students' attitudes towards using video materials in teaching 
listening skills. A sample of 41 first- year English major students was randomly selected and the one group pretest- posttest design was implemented in the study. The instruments of the study were lesson plans, pre and post English comprehension tests and a questionnaire of students' attitudes. The results indicated that students listening skills ability and attitudes towards using video materials were significantly developed.

Kasmani and Bengar (2013) investigated the effect of vocabulary learning strategy on the listening comprehension of EFL undergraduate students majoring in English translation. The data was collected using Schmitt's VLS questionnaire and TOEFL listening comprehension test. The results asserted the effectiveness of vocabulary learning strategy on developing listening comprehension.

Al-Yami (2008) investigated the effectiveness of scaffolding interactive activities in developing the listening comprehension skills of sixth grade students. The participants were 50 sixth grade students. They were assigned to an experimental group $(n=25)$ and a control group $(n=25)$ studied the same lessons. The experimental group used the scaffolding activities prepared by the researcher. A pre-posttest was administered to both groups and by the end of the experiment the results revealed that the scaffolding activities were very effective in developing the listening comprehension skills of sixth grade students.

The following are some studies related to speaking skill:

Salem (2017) investigated the effect of a webquest- based program to develop the EFL listening and speaking skills of secondary stage students and their self-regulation. The sample consisted of 40 participants of the second year general secondary school students divided into two groups, the experimental group $(n=20)$ was taught through the webquest, and the control group $(n=20)$ taught through the traditional way. The researcher used the following instruments: a listening sub-skills checklist, a speaking sub-skills checklist, a computer and internet survey to choose the sample, two pre posttest listening and speaking, a speaking assessment rubric, SelfRegulation Questionnaire (SRQ), and a reflection log for students to evaluate the program. The results of the revealed that there was a statistically significant difference in the mean scores of the experimental and control groups in the listening and speaking posttest and self-regulation questionnaire in favor of the experimental group.

Bastian and Reinhardt (2016) examined The influence of intercultural communication on secondary school students and their acquisition of English speaking and discussion skills in a $3 \mathrm{D}$ virtual world environment. 
The participants were seventeen secondary school students. The students were asked to carry out some tasks in the OpenSim environment and to practice their discussion skills amongst themselves, with limited teacher input. The results were gathered through questionnaires and interviews, moreover, students' discussions and English abilities were tested and analyzed before and after the course. The results showed that the overall effect of the course on the students was positive.

Muslim and Abbas (2016) conducted a study to investigate the effects of the immersive multimedia learning technique with peer support on performance in English in terms of oral production skills speaking and reading that involved six measures; phrasing, stress, pausing, rate, intonation and integration. The quasi-experimental $2 \times 2$ factorial design with a pre posttest was employed for the study, the first factor was immersive multimedia learning while the second factor was comprised achievement in English. The participants were 80 first year university students and the treatment lasted for 8 weeks. The findings showed that the immersive multimedia learning with peer support group reported significantly better performance in all measures of oral production for reading and speaking.

Rahayu (2016) examined the effectiveness of using video-recorded speaking task on students' speaking skill. The researcher adopted the quasiexperimental design with $8710^{\text {th }}$ grade students classified into two classes, experimental and control groups. Data were collected through a pre posttest and a questionnaire consisted of five questions asking students opinion about the video-recorded speaking task. The results revealed that there was a statistically significant difference in the mean scores of the posttest in favor of the experimental group which means that the using of videorecorded speaking task was effective in improving students' speaking skills.

Zarandi and Rahbar (2016) conducted a study to investigate the effectiveness of intervening scaffolding strategies on Iranian EFL learners' speaking skill. The sample consisted of 60 Iranian EFL learners selected according to their performance on Oxford Placement Test (OPT). They were divided to two equal groups experimental and control. The experimental group received the course using the intervening scaffolding by providing learners with flexible opportunities to use their skills, knowledge and strategies in different context, while the control group studied using the traditional techniques of speaking instruction. The findings of the study asserted the effective role of the intervening scaffolding strategies in developing students' speaking skills. 
Below are some studies related to self-directed learning:

Khodary (2017) examined the effect of Edmodo use on developing Saudi English as a Foreign Language (EFL) students' Self-Directed Learning (SDL). It employed a quasi-experimental design that included a one group design. The participants $(n=45)$ were all fifth level students at Languages and Translation Department, Arar Faculty of Education and Arts, Northern Border University, Kingdom of Saudi Arabia. They were pretested before the treatment by using the pre Personal Responsibility Orientation to Self-Direction in Learning Scale (PRO-SDLS). They were post-tested after the treatment by using the post PRO-SDLS. The results revealed that a statistically significant difference in the participants' SDL between the pre PRO-SDLS and the post PRO-SDLS in favor of the post PRO-SDLS.

Akgunduz and Akinoglu (2016) investigate the effect of blended learning and social media supported learning on the students' attitude and self-directed learning skills in Science Education. This research took place with the 7th grade 74 students attending to a primary school in Kadikoy, Istanbul. The design of the study was pretest-posttest control group design. Control Group is taught by using the traditional face to face approach with the $5 \mathrm{E}$ learning cycle, one of the experimental groups received blended learning model (face to face and internet based learning) with the $5 \mathrm{E}$ learning cycle and the other experimental group received social networking supported based on face to face approach and the 5E learning cycle model. Data were collected using the Science Teaching Attitude Scale and the Selfdirected Learning Skills Scale. The results indicated that, while blended learning experimental group increase science attitude and self-directed learning skills significantly than the control group; social media supported learning group has a positive impact on attitude and self-directed learning skills, although this change didn't make a significant difference compared with the control group.

Hematian, Rezaei\& Mohammadyfar (2016) sought a study aimed to investigate the effect of goal setting on self-directed learning. The number of 40 students with the lowest scores in self-directed learning and achievement motivation from secondary school students at eighth grade was randomly selected as the sample and were divided into two experimental and control groups. Pre and post-test, Self-Directed Learning Readiness Scale and Herman's Questionnaire Measure of Achievement Motivation were used for data collection purposes. The results showed that teaching of goal setting had a significant effect on the improvement of self-directed 
learning and achievement motivation; however, it had no significant effect on students' academic achievement. According to the obtained results, it is recommended that goal setting be taught to promote self-directed learning and achievement motivation.

Küçüker, Selvi (2015) aimed to develop self-directed learning (SDL) skills of primary school students attending 1st-4th years and to design a selfdirected learning model (PTSSDLM) for $4^{\text {th }}$ grades. Data obtained during intervention weeks and at the end of the research were collected with audio records, field notes, researcher daily, students' work sheets, reliability and validity committee's meeting records, self-evaluation form, interviews done with students and class teacher. Findings obtained from data analysis revealed that students' usage level of SDL planning skills were increased during the intervention.

Conradie (2014), conducted a study to support self-directed learning by connectivism and personal learning environments. The aim of the study was to examine the use of a connectivism pedagogical approach through the use of personal learning environments to support self-directed learning. The participants were 76 learners at the fourth year Information and Communication Technology (ICT) class. Semi-structured interviews were performed utilizing an interview guide with both open and closed-ended questions. The results revealed that learners found the new pedagogical approach challenging, requiring critical thinking from them on the course curriculum and information set. Results also indicated the possible need for additional scaffolding for learners in the use of personal learning environment and self-regulated learning.

Below are some studies related to the effect of MOOCs on enhancing different skills:

Almutairi (2018) examined the impact of integrating elements of Massive Open Online Courses (MOOCs) into the on-campus learning of Saudi women's higher educational institutions with emphasis in students' engagement. A preliminary study was conducted to develop a model that could help measure students' engagement in the context of a blendedMOOC. The experimental design was used to identify any differences in the impact on student engagement between the face-to- face learning and blended-MOOC approaches. A fourteen-week experiment took place at three different Saudi women's universities with one hundred and eight participants divided into two groups. The confirmed model, interviews with lecturers, as well as the researcher's reflections and notes were all used in order to assess the change in student engagement. The results of the study 
reveal that students who were exposed to the blended-MOOC design became more indicators and that the more the students used the MOOC system for educational activities, the more they engaged in their learning process.

Khair (2018) conducted a study to examine the Effect of Note-Taking Techniques in Massive Open Online Course (MOOC) towards Listening Comprehension of English Department Students. The study aims at figuring out stenography techniques used by students and finding out whether there is a significant difference between listening comprehension before and after treatment. This pre-experimental study employed 30 English Department students who enrolled in Analytical Listening Class with a mix-method approach. Listening comprehension pre-test and post-test were disseminated. The result shows that listening comprehension improved in post-test and there is a significant difference between listening comprehension before and after treatment.

Djawhara (2016) conducted a study to investigate the effectiveness of the Massive Open Online Courses (MOOCs) in developing listening comprehension skills among Algerian EFL university students. To achieve this purpose, a survey was administered to the sample of the research that included seventy learners from different department of Algerian universities. Their levels vary between License, Master and doctorate. The findings of the research reveal that the MOOC is a beneficial tool for the development of listening comprehension. The findings also reveal statistically that participants were ready for using MOOCs as a supplement material in the language learning process; most of them expressed positive attitudes towards MOOCs to be used as a tool to develop listening comprehension.

Davis (2016) sought a study to report on two large-scale MOOCs aimed at improving users' oral English skills. One course was hosted on a Chinese platform and one on a global platform that attracted users from nearly 200 countries. The course attracted 31,904 registered users, with the largest numbers of students located in or near the most economically prosperous areas in China. Students were graded on their performance in listening comprehension quizzes and a final speaking exam asked students to record a short passage in response to one of three prompts related to course themes; these recordings were assessed through a combination of automatic grading by software designed by Pigaiwang (www.pigai.org), and through manual grading by course staff. The findings suggested several directions for future research in order to investigate how the MOOC format 
might be optimized for language instruction. There appears to be high demand from students for language instruction MOOCs, but much work remains to be done before they can be seen as valuable and effective pedagogical tools.

Freihat and Al-Zamil (2014) investigated the effectiveness of a Massive Open Online Course (MOOC) on developing listening skills among Saudi EFL university students. To achieve this purpose, a listening was prepared and administered. Then, a MOOC was designed, programmed, and presented to the students to develop their listening skills. The sample of the research included forty level-one, English major students. They were randomly selected to be included in the experimental group $(\mathrm{N}=20)$ and the control group $(\mathrm{N}=20)$. Findings of the research revealed that the MOOC has been effective in the development of specific listening skills. The findings also revealed statistically significant differences between the post-test mean scores in all listening skills, namely, intensive, selective, and extensive which were in favor of the experimental group.

Related literature suggests that using MOOC for teaching language skills allows the possibility of numerous positive outcomes. By working independently, learners are likely to become more aware of their personal learning styles and thereby discover how best they can perfect their own skills and promote their own language learning. Due to its efficiency as a teaching technique, MOOCs have been widely investigated with many other educational and psychological variables which are all related to the teaching/learning process such as students' engagement by Almutairi, (2018); workforce development education by Chan, (2016); education and the competitive recovery of Portugal by Bello, (2014); attitudes, performance and academic achievement by Lacheheb, (2013); students' perception of blended learning by Bruff, et al , (2013); and English language education by Anazi, (2013).

\section{Problem of the Study}

Based on the literature review, pilot study and researchers' experience, it was evident that EFL secondary students need improvement in both listening and speaking skills. Thus, the current study investigated the effect of a proposed Massive Open Online Course (MOOC) to develop EFL secondary school students' listening and speaking skills and their selfdirected learning.

\section{Questions}

The study attempted to answer the following questions:

1- What are the features of the proposed MOOC? 
2- What are the most interesting topics that students would like to discuss during the MOOC?

3- To what extent will the proposed MOOC help in developing secondary school students' listening skills?

4- To what extent will the proposed MOOC help in developing secondary school students' speaking skills?

5- To what extent will the proposed MOOC help in developing secondary school students' self- directed learning?

\section{Hypotheses}

In this study, the researcher tested the following hypotheses:

1- There was a statistically significant difference at the 0.05 level between the mean ranks of the experimental group on the pre and post administrations of the EFL listening skills test in favor of the post test.

2- There was a statistically significant difference at the 0.05 level between the mean ranks of the experimental group on the pre and post administrations of the EFL speaking skills test in favor of the post test.

3- There was a statistically significant difference at the 0.05 level in the mean ranks of the experimental group in the pre and post administration of the self-directed learning scale in favor of the post administration.

\section{Definition of Terms MOOCs:}

The current study defines MOOCs as a new free technology that enables participants to be lifelong learners who are able to receive the information and materials they need to reach their goals away from the traditional learning environment.

\section{Listening Skill:}

The current study defines the listening skill as the process of receiving and comprehending certain messages with the purpose of communicating and responding in a meaningful way.

\section{Speaking skill:}

The current study defines speaking skill as one of the most demanding and crucial tasks that should be developed to communicate effectively, to build self- confidence and to gain success in relations, school and workplace.

\section{Self-Directed Learning:}

The researcher defines self-directed learning as the process that helps students to be independent learners and to be in charge of their own learning 
by selecting the information, strategies and skills they need to develop without others' help.

\section{Method}

\section{Sample}

The sample of the study was one experimental group $(n=20)$ of EFL $1^{\text {st }}$ year secondary school students at Future Language Schools in Tanta city in the academic year 2019/2020 that was taught using a MOOC created by the researcher.

\section{Design}

The study adopted the quasi-experimental design using one experimental group pre-posttest. The experimental group was taught using a Massive Open Online Course (MOOC) created by the researcher employing authentic materials.

\section{Instruments}

The following instruments were designed and used in the study by the researcher:

1- Course Topics Checklist (CTC)

2- Listening Skills Test (LST)

3- Speaking Skills Test (SST)

4- Personal Responsibility Orientation to Self-Directed Learning Scale (Pro-SDLS)

\section{Results and Discussion}

The results of the study were statistically analyzed and reported in terms of its sub- hypotheses

\section{1- Verifying the first hypothesis:}

Wilcoxon Signed Ranks-test for dependent samples was used to test the first hypothesis which addressed the differences between the experimental group on the pre and post administrations of the EFL listening test. Table (1) shows the result: 
Table (1)

Comparing the performance of the experimental group on the pre and post-administrations of the EFL Listening test

\begin{tabular}{|c|c|c|c|c|c|c|c|c|}
\hline Variables & Ranks & $N$ & $\begin{array}{l}\text { Mean } \\
\text { Rank }\end{array}$ & $\begin{array}{l}\text { Sum of } \\
\text { Ranks }\end{array}$ & $Z$ & $\begin{array}{l}\text { Effect } \\
\text { size }\end{array}$ & $\begin{array}{l}\text { Level of } \\
\text { effect } \\
\text { size }\end{array}$ & $\begin{array}{l}\text { Sig. }(2- \\
\text { tailed })\end{array}$ \\
\hline \multirow[t]{4}{*}{$\begin{array}{l}\text { Listening for the } \\
\text { main idea }\end{array}$} & $\begin{array}{l}\text { Negative } \\
\text { Ranks }\end{array}$ & 3 & 5 & 15 & \multirow[t]{4}{*}{1.7} & \multirow[t]{4}{*}{ - } & \multirow[t]{4}{*}{ - } & \multirow{4}{*}{$\begin{array}{l}\text { Not } \\
\text { significant }\end{array}$} \\
\hline & $\begin{array}{l}\text { Positive } \\
\text { Ranks }\end{array}$ & 8 & 6.38 & 51.00 & & & & \\
\hline & Ties & 9 & & & & & & \\
\hline & Total & 20 & & & & & & \\
\hline \multirow[t]{4}{*}{$\begin{array}{l}\text { Listening for } \\
\text { specific details }\end{array}$} & $\begin{array}{l}\text { Negative } \\
\text { Ranks }\end{array}$ & 0 & 00 & 00 & \multirow[t]{4}{*}{3.531} & \multirow[t]{4}{*}{0.79} & \multirow[t]{4}{*}{ High } & \multirow{4}{*}{$\begin{array}{l}\text { Significant } \\
\text { at } 0.05\end{array}$} \\
\hline & $\begin{array}{l}\text { Positive } \\
\text { Ranks } \\
\end{array}$ & 15 & 8 & 120 & & & & \\
\hline & Ties & 5 & & & & & & \\
\hline & Total & 20 & & & & & & \\
\hline \multirow{4}{*}{$\begin{array}{l}\text { Guessing the } \\
\text { meaning of } \\
\text { difficult words }\end{array}$} & $\begin{array}{l}\text { Negative } \\
\text { Ranks }\end{array}$ & 3 & 5 & 15 & \multirow[t]{4}{*}{3.14} & \multirow[t]{4}{*}{0.70} & \multirow[t]{4}{*}{ High } & \multirow{4}{*}{$\begin{array}{l}\text { Significant } \\
\text { at } 0.05\end{array}$} \\
\hline & $\begin{array}{l}\text { Positive } \\
\text { Ranks }\end{array}$ & 15 & 10.4 & 156 & & & & \\
\hline & Ties & 2 & & & & & & \\
\hline & Total & 20 & & & & & & \\
\hline \multirow[t]{4}{*}{$\begin{array}{l}\text { Making } \\
\text { inferences }\end{array}$} & $\begin{array}{l}\text { Negative } \\
\text { Ranks }\end{array}$ & 1 & 6 & 6 & \multirow[t]{4}{*}{3.34} & \multirow[t]{4}{*}{0.75} & \multirow[t]{4}{*}{ High } & \multirow{4}{*}{$\begin{array}{l}\text { Significant } \\
\text { at } 0.05\end{array}$} \\
\hline & $\begin{array}{l}\text { Positive } \\
\text { Ranks } \\
\end{array}$ & 15 & 8.67 & 130 & & & & \\
\hline & Ties & 4 & & & & & & \\
\hline & Total & 20 & & & & & & \\
\hline \multirow[t]{4}{*}{$\begin{array}{l}\text { Listening for } \\
\text { gist }\end{array}$} & $\begin{array}{l}\text { Negative } \\
\text { Ranks }\end{array}$ & 0 & 00 & 00 & \multirow[t]{4}{*}{3.95} & \multirow[t]{4}{*}{0.88} & \multirow[t]{4}{*}{ High } & \multirow{4}{*}{$\begin{array}{l}\text { Significant } \\
\text { at } 0.05\end{array}$} \\
\hline & $\begin{array}{l}\text { Positive } \\
\text { Ranks }\end{array}$ & 20 & 10.5 & 210 & & & & \\
\hline & Ties & 0 & & & & & & \\
\hline & Total & 20 & & & & & & \\
\hline \multirow[t]{4}{*}{ Total } & $\begin{array}{l}\text { Negative } \\
\text { Ranks }\end{array}$ & 0 & 00 & 00 & \multirow[t]{4}{*}{3.93} & \multirow[t]{4}{*}{0.88} & \multirow[t]{4}{*}{ High } & \multirow[t]{4}{*}{$\begin{array}{l}\text { Significant } \\
\text { at } 0.05\end{array}$} \\
\hline & $\begin{array}{l}\text { Positive } \\
\text { Ranks }\end{array}$ & 20 & 10.5 & 210 & & & & \\
\hline & Ties & 0 & & & & & & \\
\hline & Total & 20 & & & & & & \\
\hline
\end{tabular}

Results in table (1) illustrate that the estimated t-value is significant at 0.05 level. This reflects that there are statistically significant differences between the mean ranks of the pre and post-administration of the EFL listening test in the five sub-skills and in the total score but it was not significant in the first sub-skill (listening for the main idea). This nonsignificant result can be attributed to the simplicity of this sub-skill along 
with the high level of the participants who could easily get the main idea of any listening record. The high effect size of the total score $(0.88)$ revealed the positive effect of the MOOC on students' listening skills. Therefore, the first hypothesis of the study was verified and accepted.

\section{2- Verifying the second hypothesis:}

Wilcoxon Signed Ranks-test for dependent samples was used to test the second hypothesis which addressed the differences between the experimental group on the pre and post administrations of the EFL speaking test. Table (2) shows the result:

Table (2)

Comparing the performance of the experimental group on the pre and post-administration of the EFL speaking test

\begin{tabular}{|c|c|c|c|c|c|c|c|c|}
\hline Variables & Ranks & $N$ & $\begin{array}{l}\text { Mean } \\
\text { Rank }\end{array}$ & $\begin{array}{c}\text { Sum of } \\
\text { Ranks }\end{array}$ & $Z$ & $\begin{array}{l}\text { Effect } \\
\text { size }\end{array}$ & $\begin{array}{c}\text { Level of } \\
\text { effect } \\
\text { size }\end{array}$ & $\begin{array}{l}\text { Sig. }(2- \\
\text { tailed })\end{array}$ \\
\hline \multirow[t]{4}{*}{ Accuracy } & $\begin{array}{c}\text { Negative } \\
\text { Ranks }\end{array}$ & 0 & 00 & 00 & \multirow{4}{*}{3.906} & \multirow{4}{*}{0.87} & \multirow{4}{*}{ High } & \multirow{4}{*}{$\begin{array}{l}\text { Significant } \\
\text { at } 0.05\end{array}$} \\
\hline & $\begin{array}{c}\text { Positive } \\
\text { Ranks }\end{array}$ & 18 & 9.5 & 171.00 & & & & \\
\hline & Ties & 2 & & & & & & \\
\hline & Total & 20 & & & & & & \\
\hline \multirow[t]{4}{*}{ Fluency } & $\begin{array}{c}\text { Negative } \\
\text { Ranks }\end{array}$ & 0 & 00 & 00 & \multirow{4}{*}{3.578} & \multirow{4}{*}{0.80} & \multirow{4}{*}{ High } & \multirow{4}{*}{$\begin{array}{l}\text { Significant } \\
\text { at } 0.05\end{array}$} \\
\hline & $\begin{array}{c}\text { Positive } \\
\text { Ranks }\end{array}$ & 15 & 8 & 120 & & & & \\
\hline & Ties & 5 & & & & & & \\
\hline & Total & 20 & & & & & & \\
\hline \multirow[t]{4}{*}{ Pronunciation } & $\begin{array}{c}\text { Negative } \\
\text { Ranks }\end{array}$ & 0 & 00 & 00 & \multirow[t]{4}{*}{4.035} & \multirow{4}{*}{0.90} & \multirow[t]{4}{*}{ High } & \multirow{4}{*}{$\begin{array}{l}\text { Significant } \\
\text { at } 0.05\end{array}$} \\
\hline & $\begin{array}{c}\text { Positive } \\
\text { Ranks }\end{array}$ & 20 & 10.5 & 210 & & & & \\
\hline & Ties & 0 & & & & & & \\
\hline & Total & 20 & & & & & & \\
\hline \multirow[t]{4}{*}{ Vocabulary } & $\begin{array}{c}\text { Negative } \\
\text { Ranks }\end{array}$ & 0 & 00 & 00 & \multirow[t]{4}{*}{4.030} & \multirow[t]{4}{*}{0.90} & \multirow[t]{4}{*}{ High } & \multirow{4}{*}{$\begin{array}{l}\text { Significant } \\
\text { at } 0.05\end{array}$} \\
\hline & $\begin{array}{c}\text { Positive } \\
\text { Ranks }\end{array}$ & 20 & 10.5 & 210 & & & & \\
\hline & Ties & 0 & & & & & & \\
\hline & Total & 20 & & & & & & \\
\hline \multirow[t]{4}{*}{ Total } & $\begin{array}{c}\text { Negative } \\
\text { Ranks }\end{array}$ & 0 & 00 & 00 & \multirow[t]{4}{*}{3.95} & \multirow[t]{4}{*}{0.88} & \multirow[t]{4}{*}{ High } & \multirow[t]{4}{*}{$\begin{array}{l}\text { Significant } \\
\text { at } 0.05\end{array}$} \\
\hline & $\begin{array}{c}\text { Positive } \\
\text { Ranks }\end{array}$ & 20 & 10.5 & 210 & & & & \\
\hline & Ties & 0 & & & & & & \\
\hline & Total & 20 & & & & & & \\
\hline
\end{tabular}

Results in table (2) illustrate that the estimated t-value is significant at 0.05 level. This reflects that there are statistically significant differences 
between the mean ranks of the pre and post-administration of the EFL speaking test in the four sub-skills and in the total score. These significant differences are in favor of the post-test. The table also illustrates the effect size of the MOOC on the four speaking sub-skills of the experimental group students under investigation. Results indicated that the effect size was high in the four speaking sub-skills. Thus, the second hypothesis was verified and accepted.

\section{3- Verifying the third hypothesis:}

Wilcoxon Signed Ranks-test for dependent samples was used to test the third hypothesis which addressed the differences between the experimental group on the pre and post administrations of the SDLS. Table (3) shows the result:

Table (3)

Comparing the performance of the experimental group on the pre and post- administrations of the SDLS

\begin{tabular}{|l|c|c|c|c|c|c|c|c|}
\hline Variables & Ranks & $\boldsymbol{N}$ & $\begin{array}{c}\text { Mean } \\
\text { Rank }\end{array}$ & $\begin{array}{c}\text { Sum of } \\
\text { Ranks }\end{array}$ & $\boldsymbol{Z}$ & $\begin{array}{c}\text { Effect } \\
\text { size }\end{array}$ & $\begin{array}{c}\text { Level of } \\
\text { effect size }\end{array}$ & $\begin{array}{c}\text { Sig. (2- } \\
\text { tailed) }\end{array}$ \\
\hline \multirow{3}{*}{ Total } & $\begin{array}{c}\text { Negative } \\
\text { Ranks }\end{array}$ & 0 & 00 & 00 & \multirow{2}{*}{3.93} & 0.88 & High & $\begin{array}{c}\text { Significant } \\
\text { at } 0.05\end{array}$ \\
\cline { 2 - 8 } & $\begin{array}{c}\text { Positive } \\
\text { Ranks }\end{array}$ & 20 & 10.5 & 210 & & & \\
\cline { 2 - 4 } & Ties & 0 & & & & & & \\
\cline { 2 - 8 } & Total & 20 & & & & & \\
\hline
\end{tabular}

The results in (table 3 ) reveal that the mean ranks of the experimental group members on the post administration of the scale was 10.5 which was noticeably high and statistically significant when compared with their own mean scores on the pre administration of the same questionnaire. Increasingly, the effect size of the MOOC is also remarkably high as the $\mathrm{z}$ value was (3.93) and the $\square 2$ was 0.88 . This indicated that the MOOC was very effective in enhancing or boosting the participants' self-directed learning. The results also proved that the statistical differences between the pre-post administration of the SDLS are in favor of the post administration. Therefore, the third hypothesis of the study is proved and accepted.

The large effect size of the MOOC on students' listening and speaking skills is so much attributed to the different activities and exercises used in the MOOC along with the authentic materials that students were asked to use and practice. Students also liked the idea of recording themselves because they were sure that no one would listen to these audios except for the researcher, so they didn't feel shy of being judged by their classmates and they weren't afraid of making mistakes the thing which helped them to develop their speaking skill efficiently. 
In the same context, the large effect size of students' self-directed learning could be due to the tasks and activities they were asked to do during the course; they needed to collect and organize information, to choose the proper time to practice every lesson, to take quizzes and evaluate their performance, to do speaking tasks alone or with another person, to be able to use the internet and the website in their own and to be self-monitors to their performance during the course. These actions were all self-directed learning skills

These results are consistent with the studies of (Almutairi, 2018; Khair, 2018; Djawhara, 2016; Davis, 2016; Chan, 2016; Freihat and AlZamil, 2014; Bello, 2014; Anzai, 2013; Lachheb, 2013; and Fini, 2009) all of which emphasized the effect of using MOOCs on different aspects of language teaching and on different students' levels.

\section{Conclusion:}

The effectiveness of using the Massive Open Online Course (MOOC) was evident in improving most of the listening and speaking skills of the experimental group students. It was also able to develop their self-directed learning in a reasonable way. Moreover, students showed positive attitude towards the experiment as it helped them to be responsible for their own learning. They also felt the difference in their listening and speaking performance before and after the experiment.

Therefore, the current study proved the effectiveness of using MOOCs in developing students' listening and speaking skills in addition to their selfdirected learning

\section{Recommendations}

Based on the results of the present study, the following recommendations are suggested:

1- Decision makers at the Ministry of Education should offer Massive Open Online Courses (MOOCs) via internet in all fields of English and other different subjects to secondary school students to widen their knowledge and increase their information.

2- Teachers should train their students to be self-directed learners, that is to search the information themselves, learn, manage, control, monitor and evaluate their learning process.

3- Educational experts and MOE should familiarize their teachers with the importance of self-directed learning and supply them with trainings to help them teach their students to be autonomous learners.

4- Teachers should also be supplied with training courses to help them use the internet tools appropriately to be able to integrate technology in 
the process of learning and to create materials suitable with the new demands of education.

5- Strong interest in listening and speaking skills should be taken into consideration by English teachers especially by using authentic materials that would help students understand spoken English in different situations and be able to express themselves appropriately.

6- Reflection Logs should be activated inside the classrooms to help students assess themselves and their own learning.

7- Egyptian Universities should offer MOOCs to university students as a new learning landscape which can complement the current teaching without harming education and to increase the quality of teaching in universities and colleges.

8- University students should be familiarized with the importance of enrolling in MOOCs of different topics in order to be lifelong learners and develop their self-directed learning abilities.

\section{References}

Akgunduz, D., \& Akinoglu, O. (2016). The Effect of Blended Learning and Social Media-Supported Learning on the Students' Attitude and Self-Directed Learning Skills in Science Education. TOJET: The Turkish Online Journal of Educational Technology, 15(2), P.10.

Allen, E. \& Seaman, J. (2014). Changing Course: Ten Years of Tracking Online Education in the United States. Babson Survey Research Group and Quahog Research Group, LLC. Retrieved from: http://www.onlinelearningsurvey.com/reports/gradechange.pdf

Almutairi, F. (2018). The Impact of Integrating MOOCs into Campus Courses on Student Engagement (Doctoral dissertation, University of Southampton).

Al-Yami, S. A. (2008). The Effectiveness of Scaffolding Interactive Activities in Developing the English Listening Comprehension Skills of the Sixth Grade Elementary Schoolgirls in Jeddah. Online Submission.

Anzai, Y. (2013). What about MOOCs for language learning? In T. Bastiaens\& G. Marks (Eds.), Proceedings of World Conference on ELearning in Corporate, Government, Healthcare, and Higher Education 2013 (pp. 557-561). Chesapeake, VA: AACE.

Areglado, R., Bradley, R., \& Lane, P. (1996). Learning for Life: Creating Classrooms for Self-Directed Learning. Thousand Oaks, CA: Corwin Press, Inc. 
Bastian, P., \& Reinhardt, D. (2016). The influence of intercultural communication on secondary school students and their acquisition of English speaking and discussion skills in a 3D virtual world environment: A case study (Master's thesis).

Bello, M. M. D. S. D. (2015). The strategic role of MOOCs in education and its effects on the competitive recovery of Portugal (Doctoral dissertation).

Candy, P. (1991) Self-direction for lifelong learning: A Comprehensive Guide to Theory and Practice. San Francisco: Jossey-Bass.

Chan, M. M. (2016). MOOC Phenomenon: Building an Effective and Sustainable Program.

Conradie, P. W. (2014). Supporting self-directed learning by connectivism and personal learning environments. International Journal of Information and Education Technology, 4(3), 254

Davis, G. M. (2016). User Engagement in a Series of MOOCs for Oral English Skills. First published May, 2016 by The Hong Kong Polytechnic University Hung Hom, Kowloon, Hong Kong Sponsored by Tsinghua University Initiative Scientific Research Program.

Djawhara, B. (2016). Developing EFL Learners' Listening Comprehension through Massive Open Online Courses a Case Study of Students at Algerian Universities (Doctoral dissertation).

Downes, S. (2010). Vision Statement. Stephen's Web. Retrieved from http://www.downes.ca/

Fini, A. (2009). The technological dimension of a massive open online course: The case of the CCK08 course tools. The International Review of Research in Open and Distance Learning. Retrieved from http://www.irrodl.org/index.php/irrodl/article/view/643/1402.

Freihat, N. (2014). The Effect of Integrating MOOC'S on Saudi Female Students' Listening Achievement. European Scientific Journal, ESJ, 10(34).

Gibbons, M. (2002). The self-directed learning handbook: Challenging adolescent students to excel. San Francisco, CA: Jossey-Bass.

Hematian, F., Rezaei, A. M., \& Mohammadyfar, M. A. (2016). On the Effect of Goal Setting on Self-Directed Learning, Achievement Motivation, and Academic Achievement among Students. Modern Applied Science, 11(1), 37.

Herman, R. (2012). The MOOCs are coming. The Journal of Effective Teaching, 12(2), 1-3. Retrieved from: http://www.uncw.edu/cte/ET/articles/Vol12_2/Editor.pdf 
Jossberger, H., Brand-Gruwel, S., Boshuizen, H., \& Wiel, M. (2010). The challenge of self-directed and self-regulated learning in vocational education: a theoretical analysis and synthesis of requirements. Journal of Vocational Education and Training, 62(4), 415-440. https://doi.org/10.1080/13636820.2010.523479

Kasmani, M. B., \& Bengar, A. S. (2013). The effect of vocabulary learning strategies of EFL undergraduate students on their listening comprehension ability. Asian Journal of Social Sciences \& Humanities, 2(1), 253-259.

Khair, I., \& Syukri, M. A. (2018) The Effect of Note-Taking Techniques in Massive Open Online Course (MOOC) towards Listening Comprehension of English Department Students. Anglicist, 7 (1), 5766.

Khodary, M. M. (2017). Edmodo Use to Develop Saudi EFL Students' Self-Directed Learning. English Language Teaching, 10(2), 123.

Kop, R., \& Hill, A. (2008). Connectivism: Learning theory of the future or vestige of the past? International Review of Research in Open and Distance Learning, 9(3). Retrieved from: http://www.irrodl.org/index.php/irrodl/article/view/523/1103

Küçüker, G. F., \& Selvi, K. (2016). A Proposal Of Teacher-Supported Model For Developing Primary School Students' Self-Directed Learning Skills (PTSSDLM). Egitim ve Bilim, 41(185).

Lachheb, A. (2013). Information Technology Effects on Tunisian College Students; Tunisian English Majors as a Case Study. In M. Searson\& M. Ochoa (Eds.), Proceedings of Society for Information Technology \& Teacher Education International Conference 2014 (pp. 1990-1995). Chesapeake, VA: AACE.

Muslim\& Abbas. (2016). The Effects of Immersive Multimedia Learning with Peer Support on English Oral Skills. PROSIDING ICTTE FKIP UNS 2015, 1(1)

O'Shea, E. (2003). Self-directed learning in nurse education: A review of the literature. Journal of Advanced Nursing, 43(1), 62-70. https://doi.org/10.1046/j.1365-2648.2003.02673.x

Rahayu, R. (2016). the effectiveness of using video-recorded speaking task on students' speaking skill. Faculty of Tarbiya and Teachers' Training, State Islamic University Syarif Hidayatullah, Jakarta.

Richards, J. C. 2008. Teaching Listening and Speaking: From Theory to Practice. New York: Cambridge University Press. 
Salem, A. S. (2017). A WebQuest-Based Program (WQBP) to develop the EFL listening and speaking skills of secondary stage Students and their Self-Regulation. PhD thesis, Mansoura University, Faculty of Education.

Samudra, D. B. S. S. B. (2016). Developing Video-Assisted Tasks in The Learning of Listening and Speaking Skills for Grade XI Students of SMA N 1 Wates. English Language Teaching Journal, 5(2).

Saqr, B.G. (2016). The effectiveness of flipped classroom approach on improving EFL preparatory school students' listening comprehension skills. MA thesis, Faculty of Education, Mansoura University.

Shaikh, R. (2013). Comparison of Readiness for Self-Directed Learning in Students Experiencing Two Different Curricula in One Medical School. Gulf Medical Journal, 2, 27-31.

Tai, T. Y. (2016). Effects of discourse marker instruction on EFL learners' listening comprehension. The Asian Journal of Applied Linguistics, 3(1), 81-100.

Viswanathan, R. (2012). Teaching and Learning through MOOC. Frontiers of Language and Teaching, Vol. 3, 32-40.

Wilson, J. J. (2008). How to Teach Listening. Essex: Pearson Education Limited.

Woottipong, K. (2014). Effect of Using Video Materials in the Teaching of Listening Skills for University Students. International Journal of Linguistics, 6 (4), p. 200-212.

Zarandi, S. Z. A., \& Rahbar, B. (2016). Enhancing speaking ability through intervening scaffolding strategies. Theory and Practice in Language Studies, 6(11), 2191-2195. 